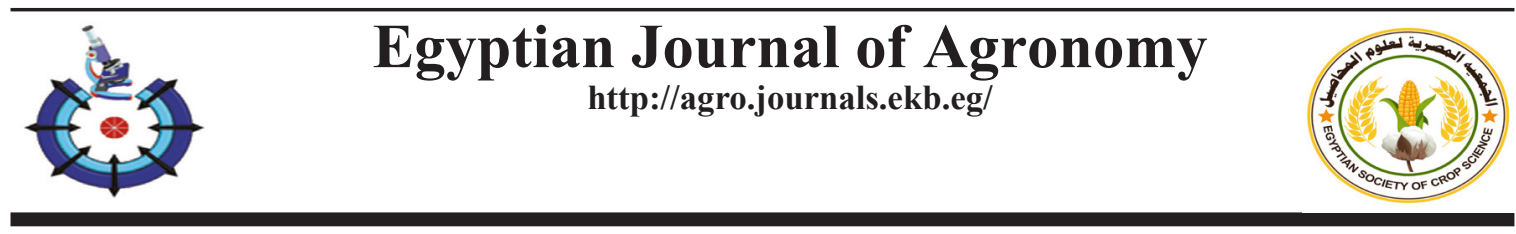

\title{
Effect of Heating by Microwave Oven on Weeds Seed Germination in Imported Shipments
}

\author{
Enas M. Kamel \\ Weed Research Central Laboratory, Agricultural Research Center, Giza, Egypt.
}

\begin{abstract}
ABORATORY and wirehouse experiments were conducted in Weed Research Central Laboratory, Agricultural Research Center, Giza, Egypt to investigate the possibility of using microwave energy to prevent the germination of weed seeds and find applicable treatments which can completely devitalize quarantine weed seeds. The present work evaluated the effect of microwave on germination of six weed species: wild oats, darnel, white bursage, Giant ragweed, field bindweed and dodder and improvement of some traits of two imported crops soybean and wheat (oil percentage of soybean seeds and protein content of wheat grains), which were contaminated by these weed species. Results showed that microwave power and time required for preventing germination varied considerably among the species studied. Microwave power $80 \%$ for $15 \mathrm{~min}$ prevented completely germination percentage of wild oats and darnel and reduced germination percentage of field bindweed to $10 \%$. The microwave power $50 \%$, $15 \mathrm{~min}$ was enough to prevent seeds germination completely and weaken dooder quarantine. In regard to Giant ragweed and white bursage, under all microwave power treatments, there were no germination of these weeds. Microwave powers $50 \%$ for $10 \mathrm{~min}$ and $80 \%$ for $15 \mathrm{~min}$ had no effect on the oil percentage extracted from soybean seeds and protein content of wheat grains, respectively. The present results suggest clearly that the exposure to microwave can weaken quarantine weed seeds in imported soybean and wheat without injury of oil percentage of soybean seeds and protein content of wheat grains.
\end{abstract}

Keywords: Germination, Inhibition, Microwave, Quarantine, Weeds seeds.

\section{Introduction}

The great majority of different weed seeds have been introduced by shipments import through world trade road. The transportation of invasive alien species had significant impacts on the recipient ecosystems and has caused major economic losses in agriculture production.

Studies have been undertaken to use microwave energy: to improve storage preserve crops, provide new natural method to weed control quarantine purposes and seed better quality. Microwave heating for quarantine control of pests in dry materials, such as wood, has been accepted internationally. This technology is now recognized, by the Food and Agriculture Organization (FAO) and implemented in the "International Standards for Phytosanitary Measures" (Bisceglia et al. 2009). Long exposure usually cause seed death (Bebawi et al. 2007). Microwave energy kills weeds and their seeds in the soil (Brodie et al., 2012, 2017). Microwave energy can also kill the roots and seeds that are buried into a depth of several centimeters in the soil (Brodie et al., 2007). The Slow-wave comb applicators can provide the required energy distribution in the surface layer, using two MWs, $30 \mathrm{~kW}(2.45 \mathrm{GHz})$ and $60 \mathrm{~kW}$ $(0.922 \mathrm{GHz})$ for heating the surface layers of weed control effectively. After $15 \mathrm{sec}$ of MW heating, the temperatures of surface reach $90-100^{\circ} \mathrm{C}$ between 60 and $120 \mathrm{~mm}$ and can provide the required top layer treatment (sterilization) with reasonable efficiency for practical use in weed seed control

Corresponding author email: enas.m2000@gmail.com Mobile: 01124979393

Received 24/5/2021; Accepted 12/8/2021

DOI: 10.21608 /agro.2021.77144.1259

C2021 National Information and Documentation Center (NIDOC) 
in agricultural applications (Brodie et al., 2020). Khan et al. (2019) reported that pre-sowing microwave soil treatment reduced the germination of weed seeds bank and increased the growth and yield of rice crop. Brodie et al. (2019) concluded that pre-sowing microwave soil treatment acts as a soil sanitation technology and increased crop yield. To decide suitable heat treatments and find field applicable methods which can completely devitalize quarantine weed seeds, the conditions for heat treatment with/without $40 \%$ relative humidity were studied with 9 species weed seeds (Geranium dissectum, Cuscuta japonica, Cuscuta pentagona, Myosotis arvensis, Centaurea solstitialis, Cirsium arvense, Cirsium vulgare, Picris echioides and Cenchrus longispinus) and one weed species (Emex spinosa) similar to quarantine weed. All seeds were dead at the conditions of $95^{\circ} \mathrm{C}$ for $48 \mathrm{hrs}, 100^{\circ} \mathrm{C}$ for $36 \mathrm{hrs}, 110^{\circ} \mathrm{C}$ for $24 \mathrm{hrs}, 121^{\circ} \mathrm{C}$ for $4 \mathrm{hrs}$ and $130^{\circ} \mathrm{C}$ for $30 \mathrm{~min}$. Heat-treatments at $40 \%$ relative humidity resulted complete seed death at $85^{\circ} \mathrm{C}$ for $36 \mathrm{hrs}$ and $90^{\circ} \mathrm{C}$ for $16 \mathrm{hrs}$ conditions (Moon et al. 2013). Dahlquist et al. (2007) studied the mortality of six weed species seeds: annual sowthistle, barnyardgrass, black nightshade, common purslane, London rocket, and tumble pigweed, at temperatures of $39,42,46,50,60$ and $70^{\circ} \mathrm{C}$ and developed nonlinear model for mortality. This model provides empirical relationship, required to developing field-applicable decision model that could predict the accumulation of time and temperature combinations for effective solarization of weed seeds. Ibrahim et al. (2016) studied the effects of various exposure times of microwave on seed germination, vegetative growth and chemical constituents. Seed germination is decreased in all seed samples with increase in exposure time from $5 \mathrm{sec}$ to $25 \mathrm{sec}$ in Acacia farnesiana and from $10 \mathrm{sec}$ to $50 \mathrm{sec}$ in Acacia saligna as compared to control treatment. The use of microwaves has an effect on the revitalization of seed germination of Acacia farnesiana and Acacia saligna under different doses, and from a protein analysis of Acacia seedlings, it was found that there is no genetic difference, which means that the microwave radiation dose was refresher for seed germination. Microwave weed and soil treatment can be implemented as an alternative method of weed control in direct-seeded rice crop (Khan \& Brodie, 2018). The exposure of cress and arugula seeds to microwaves for $126 \mathrm{sec}$ inhibited germination close to $100 \%$. Cress seeds treated with microwaves for $50 \mathrm{sec}$ showed $95 \%$ germination compared to $65 \%$ germination of the untreated cress seeds (Sahin, 2014). Seeds with intact seed coats that had not germinated were stained with triphenyl tetrazolium chloride to verify that they were dead and not dormant. Seeds were incubated at $30^{\circ} \mathrm{C}$ in triphenyl tetrazolium chloride for 6 and $24 \mathrm{hrs}$ at 0.25 and $0.5 \%$. Seed embryos stained red were considered viable, (Moore, 1973).

The purpose of this study was to overcome problematic weed seeds which contaminate imported grains. Moreover, encourage cooperation between the microwave engineering and both agricultural and forestry industries to find out many possibilities of using microwave energy to address many problems and opportunities within primary industries.

So, the aim of this work is to investigate the use of microwave heating in agricultural imports to prevent newly arrived invasive species seeds from germinating.

\section{Materials and Methods}

Series of laboratory and wirehouse experiments were conducted to determine the duration and microwave power treatments required to prevent seed germination of six weed species without affecting the oil percentage of soybean seeds and protein content of wheat grains. The six weed species studied were Avena fatua (wild oats), Lolium temulentum (darnel), cuscuta pedicellata (dodder), Ambrosia artemisifolia (white bursage), Ambrosia trifida (Giant ragweed), and Convolvulus arvensis (field bindweed) and the two imported crops: Glycine max (Soybean) and Triticum aestivum (wheat) seeds, which contaminated by these weed species. These species were selected to include winter and summer seasons weed seeds.

\section{Preparation of seeds for experiments}

Seed samples were collected from the imported wheat and soybean seeds, coming from different countries (Russia, USA, and Ukraine) from 2017 to 2020 .

Before the setting of the experiments, sowing twenty seeds of each six weed species studied in Petri dish with four replicates during the suitable season depending of each weed species (winter season 2019, for wild oat, darnel, and dodder \& spring and summer seasons 2020 and 2021 for field bindweed, white bursage and giant ragweed) under laboratory conditions, to insure these seeds 
have high viability and emergence.

\section{Germination experiments}

The date of sowing of the studied experiments was $14 / 11 / 2019$ to $15 / 4 / 2020$ for wild oats, darnel and dodder weeds, and 15/3/2020 to $15 / 4 / 2021$, for field bindweed, white bursage and giant ragweed.

As regards to Ambrosia spp. (white bursage and giant ragweed), four germination experiments with four replicates were repeated twice.

First Petri dish experiment seeds soaked in Gibberellin solution $250 \mathrm{ppm}$ concentration for $72 \mathrm{hrs}$.

Second Petri dish experiment soaked in Potassium nitrate $\left(\mathrm{KNo}_{3}\right)$ solution 1000ppm concentration for $72 \mathrm{hrs}$.

Third Petri dish experiment seeds soaked in Thiourea solution 50ppm concentration for $72 \mathrm{hrs}$.

Fourth experiment, Ambrosia spp. seeds were sowed directly in the soil, (conducted on $15 / 2 / 2021$ and repeated on 1/3/2021), twenty achenes of Ambrosia spp. collected from imported soybean seeds during the period from October to December 2020, then stored in the darkness at $0^{\circ} \mathrm{C}$ in refrigerator for three months for stratification of seeds dormancy, then soaked in fresh tap water for $72 \mathrm{hrs}$, after that, the seeds were sowed in trays filled by soil which was pasteurize by microwave heating for $3 \mathrm{hrs}$ long. After 45 days from sowing the emergence percentage was recorded.

These eight experiments were conducted at dates 15-3-2020 to 15-4-2021.

\section{Microwave treatments}

The microwave oven was used in this study, Model MOM-C25BBE-S, Tornado is registered trademark of El-Araby Company, with 230V$50 \mathrm{~Hz}$ rated voltage, $900 \mathrm{~W}$ rated output power.

Each experiment consisted of seven treatments with four replicates for each of the six weeds studied were as follows:

1 - Power $30 \%$ at $10 \mathrm{~min}\left(24^{\circ} \mathrm{C}\right)$.

2 - Power $30 \%$ at $15 \mathrm{~min}\left(45^{\circ} \mathrm{C}\right)$.

3 - Power $50 \%$ at $10 \mathrm{~min}\left(64^{\circ} \mathrm{C}\right)$.

4 - Power $50 \%$ at $15 \min \left(74^{\circ} \mathrm{C}\right)$.

5- Power $80 \%$ at $10 \min \left(130^{\circ} \mathrm{C}\right)$.

6 - Power $80 \%$ at $15 \min \left(150^{\circ} \mathrm{C}\right)$.
7- Untreated control.

Note: the previous temperatures recorded by using mercury thermometer by putting it inside the microwave oven at the end of exposure period.

Then, the seeds were removed from the microwave oven to make six petri dish experiments for the six weed species. In each experiment, five seeds from each treatment put over one filter paper/ petri dish (diameter $10 \mathrm{~cm}$ ) with four replicates and moistened with $3 \mathrm{~mL}$ of distilled water and were kept in darkness for $72 \mathrm{hrs}$ under laboratory conditions.

After that, the experiments remained for 15 days for wild oat, darnel, field bindweed and dodder weeds. While white bursage and giant ragweed remained from 21 to 30 days under natural conditions, then the seedlings (wild oat, darnel, white bursage and giant ragweed) were transplanted into the pots (diameter $25 \mathrm{~cm}$ and depth $75 \mathrm{~cm}$ and were filled with $2000 \mathrm{~g}$ soil) to study the ability of seedling to continue till the maturity stage. In regard to transplanting date was $1 / 12 / 2019$ and harvesting date was $15 / 4 / 2020$ for wild oats and darnel; while white bursage and giant ragweed transplanting date was $7 / 4 / 2020$ and harvesting date was 27/9/2020.

\section{Viability test}

Ambrosia spp. seeds with intact seed coats that didn't germinate in the germination experiments under all microwave treatments. To ensure the viability of these seeds a test was conducted by using Triphenyl Tetrazolium Chloride solution.

\section{Triphenyl tetrazolium chloride (TTC)}

When a seed is immersed in the colorless TTCsolution, the TTC penetrates into the seed tissues where it interferes with the reduction processes of the living cells by accepting a hydrogen ion.

In which, the TTC-salt is converted to a red-colored, stable, non-diffusible substance called triphenylformazan formed in the tissue, it indicates that respiratory activity is occurring in the mitochondria of seed tissue cells, which are considered alive (Peters, 2007).

The TTC test was conducted for two Ambrosia spp. seeds as following:

Achenes of Ambrosia spp. stored in the dark at $0^{\circ} \mathrm{C}$ in a refrigerator for one month before TTC 
test for stratification of seed dormancy. After this period, the achenes treated in different microwave oven powers which were as follows:

1 - Power $30 \%$ at $10 \mathrm{~min}\left(24^{\circ} \mathrm{C}\right)$.

2 - Power $30 \%$ at $15 \mathrm{~min}\left(45^{\circ} \mathrm{C}\right)$.

3 - Power $50 \%$ at $10 \mathrm{~min}\left(64^{\circ} \mathrm{C}\right)$.

4- Power $50 \%$ at $15 \min \left(74^{\circ} \mathrm{C}\right)$.

5 - Power $80 \%$ at $10 \mathrm{~min}\left(130^{\circ} \mathrm{C}\right)$.

6- Untreated control.

After the microwave power treatments were completed, the achenes were soaked in tap water at room temperature for $72 \mathrm{hrs}$, after that the achenes were cut with a surgical scalpel in a way such that the endosperm was exposed. The biggest part of the achene was used for testing and the other part was discarded. Five achenes with four replicates for each treatment were put in one small bottle and filled up with $5 \mathrm{~mL}$ of TTC solution concentration at $0.5 \%$, and then the bottle was tightly closed and kept to react at $30^{\circ} \mathrm{C}$ for $72 \mathrm{hrs}$ in darkness. After that TTC solution was poured off, achenes were rinsed under distilled water and then they were cut into halves to investigate the seeds viability.

Oil percentage of soybean seeds and protien content of wheat grains

Since the main aim of the imported soybean is the extraction of oil, so the effect of microwave treatment on the amount of extracted oil should be evaluated.

The protein content of wheat grains may be affected by heat, so the effect of microwave treatments on wheat protein content should also be evaluated.

\section{The data recorded}

1- Germination percentage (The germination percentage from each treatment divided by the average percentage germination of the untreated (control) to correct any variables beside temperatures).

2- Plant growth characteristics: Plant height, root size, number of fruit branches/plant, plant weight and root length of species as A. fatua, L. temulentum and Ambrosia spp., which were transplanted to pots to continue their growth to flowering stage.

3- Ambrosia viability (TTC test): Seeds dissecting by microscope and seeds were counted in three classes: a- Stained (= alive), b- Not stained
(= dead), no fully developed embryo present, c- Intermediate cases that are only lightly or partly stained, according to Starfinger et al. (2012).

4- Estimation of the oil percentage in soybean seeds by Soxhlet according to the methods described by A.O.A.C. (1990).

5- Total nitrogen concentration by Kjeldahl method and estimation of protein in grain wheat $(\%$ protein $=\% \mathrm{~N} \times 6.25)$ according to the methods described by A.O.A.C. (1990).

\section{Data analysis}

The experimental design was "randomized complete block design". For each of the studied species, the germination percentages were analyzed by one way ANOVA with treatments defined by microwave powers and exposure times. The dependent variable was germination percentage, from each combination of time and microwave power, values were calculated for each replication using the initial germination percentage, and the analysis was accomplished by computer software package Genstat $18^{\text {th }}$ Edition.

\section{Results and Discussion}

Effect of microwave powers for different time periods on germination percentage and growth characteristics of wild oats and darnel grains

In most cases, increasing the periods of the same microwave power from 10 to $15 \mathrm{~min}$ of the studied weed species caused a noticeable significant effect on the germination percentage of their seeds.

Data in Table 1 revealed that the microwave power $80 \%$ for $15 \mathrm{~min}, 150{ }^{\circ} \mathrm{C}$ caused significantly reduction in germination percentage $(100 \%$ reduction) of both wild oats and darnel grains in the two experiments.

The following significant reduction on germination percentage by $80 \%$ microwave power for $10 \mathrm{~min}$ was reached to $88.6 \%$ and $100 \%$ with wild oats grains and 77.8 and $100 \%$ with darnel grains in the first and the second experiments, respectively. Meanwhile, 50\% microwave power for $15 \mathrm{~min}$ gave significant reduction in germination percentage by $88.9 \%$ in wild oats grains and $21.1 \%$ in darnel grains in the second experiment.

Egypt. J. Agron. 43, No. 2 (2021) 


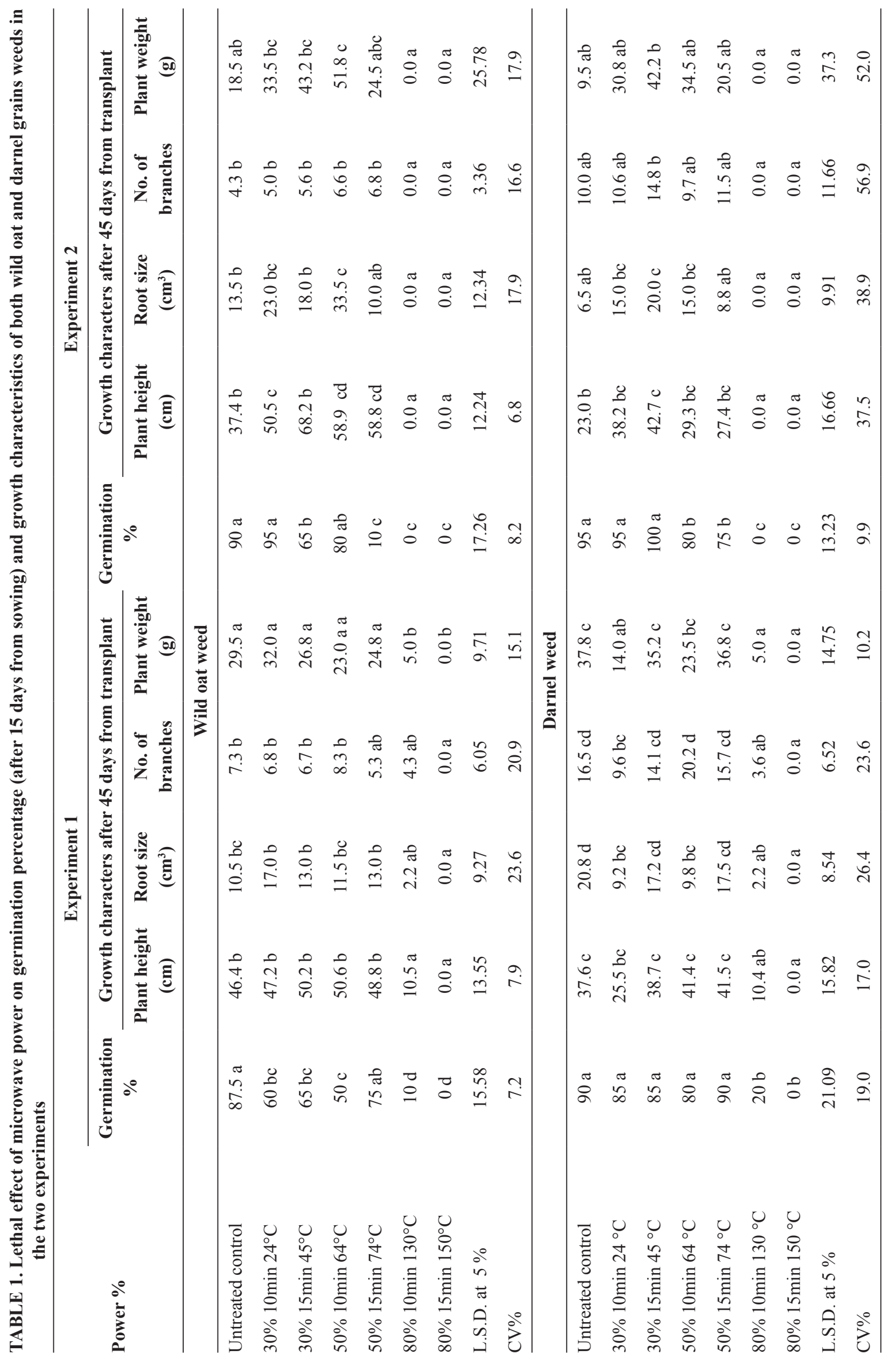

Egypt. J. Agron. 43, No. 2 (2021) 
These results are consistent with those obtained by Riemens (2003), who reported that the temperature needed for inhibition of germination and loss of viability mainly depends on the water content of the seeds and weed species. In general, temperatures ranging from $60-80^{\circ} \mathrm{C}$ are necessary for a strong inhibition of seed germination and reduction of viability of moisture seeds. On the other hand, dry seeds need higher temperatures before germination to reduce germination percentage of contaminated weed seeds and can even withstand heat exceeding $100^{\circ} \mathrm{C}$ for reducing their viability.

Moreover, the microwave powers $30 \%$ at $10 \mathrm{~min}, 30 \%$ at $15 \mathrm{~min}, 50 \%$ at $10 \mathrm{~min}$ and $50 \%$ at $15 \mathrm{~min}$ improved nursling and the growth characteristics of both wild oats and darnel weeds.

The highest significant values of plant height and number of branches $/$ plant were $50.6 \mathrm{~cm}$ and 8.3 branches/plant, respectively, were obtained from microwave power $50 \%$ for the period $10 \mathrm{~min}$, but for root size and plant weight were $17 \mathrm{~cm}^{3}$ and $32 \mathrm{~g} /$ plant, respectively, were resulted from microwave power $30 \%$ for the period $10 \mathrm{~min}$, compared to untreated control $\left(46.4 \mathrm{~cm}, 10.5 \mathrm{~cm}^{3}\right.$, 7.3 branches/plant and $29.5 \mathrm{~g} /$ plant) in the first experiment for wild oats.

Whilst, microwave powers $30 \%$ at $15 \mathrm{~min}$, $50 \%$ at $10 \mathrm{~min}, 50 \%$ at $15 \mathrm{~min}$ and $50 \%$ at $10 \mathrm{~min}$ gave the significant improvement of the previous respective growth characteristics by $(68.2 \mathrm{~cm}$, $33.5 \mathrm{~cm}^{3}, 8.6$ branches $/$ plant and $51.8 \mathrm{~g} /$ plant, respectively) compared to untreated control $\left(37.4 \mathrm{~cm}, 13.3 \mathrm{~cm}^{3}, 4.3\right.$ branches/plant and $18.5 \mathrm{~g} /$ plant, respectively) in the second experiment.
In the two experiments of darnel weed, the same trend was observed with little differences. The highest significant values of plant height, root size, plant weight were recorded with microwave power $50 \%$ at $15 \mathrm{~min}$ and for number of branches/ plant was with $50 \%$ at $10 \min$ by $\left(41.5 \mathrm{~cm}, 17.5 \mathrm{~cm}^{3}\right.$, $36.8 \mathrm{~g} /$ plant and 20.2 , respectively) compared to untreated control $\left(37.6 \mathrm{~cm}, 20.8 \mathrm{~cm}^{3}, 37.8 \mathrm{~g} / \mathrm{plant}\right.$ and 16.5, respectively) in the first experiment. Whilst, in the second experiment all the previous respective characteristics recorded the highest significant values with microwave power $30 \%$ at $15 \mathrm{~min}$ by $\left(42.7 \mathrm{~cm}, 20 \mathrm{~cm}^{3}, 42.2 \mathrm{~g} /\right.$ plant and 14.8 , respectively) compared to untreated control $\left(23.0 \mathrm{~cm}, 6.5 \mathrm{~cm}^{3}, 9.5 \mathrm{~g}\right.$ and 10.0 , respectively).

Microwave power 30\% caused improvement of the seedling due to exposure to temperature ranging from 24 to $45^{\circ} \mathrm{C}$ before sowing which caused increase of germination\%, spread of germination and vigorous growth of seedling. These results agree with those obtained by Tran (1979), Tran \& Cavanagh (1979), Bebawi et al. (2007), Moon et al. (2013) and Sahin (2014) as they reported that seeds exposure to microwave radiation caused increase in the seed germination percentage and growth characters of their seedlings while, long exposure usually causes seed death.

Effect of microwave heating on germination percentage of convolvulus arvensis and cuscuta pedicellata

The results in Table 2 showed that the germination percentage of untreated control was 40 and $31.3 \%$ in the first and the second experiments, respectively; it may be due to convolvulus arvensis seeds have dormancy or that the viability of seeds in these experiments was low.

TABLE 2. Lethal effect of microwave power on germination percentage of field bindweed and dodder

\begin{tabular}{|c|c|c|c|c|}
\hline \multirow{3}{*}{ Power \% } & \multicolumn{2}{|c|}{ Field bindweed } & \multicolumn{2}{|c|}{ Dodder } \\
\hline & \multicolumn{2}{|c|}{ Germination \% } & \multicolumn{2}{|c|}{ Germination \% } \\
\hline & Exp. 1 & Exp. 2 & Exp. 1 & Exp. 2 \\
\hline Untreated control & $40.0 \mathrm{bc}$ & $31.3 \mathrm{~cd}$ & $67.5 \mathrm{c}$ & $55 \mathrm{c}$ \\
\hline $30 \% 10 \mathrm{~min} 24^{\circ} \mathrm{C}$ & $25.0 \mathrm{abc}$ & $50.0 \mathrm{e}$ & $65 \mathrm{c}$ & $35 \mathrm{bc}$ \\
\hline $30 \% 15 \mathrm{~min} 45^{\circ} \mathrm{C}$ & $15.0 \mathrm{ab}$ & $43.8 \mathrm{de}$ & $35 \mathrm{~b}$ & $2.5 \mathrm{a}$ \\
\hline $50 \% 10 \min 64^{\circ} \mathrm{C}$ & $45.0 \mathrm{c}$ & $18.8 \mathrm{bc}$ & $0 \mathrm{a}$ & $10 a b$ \\
\hline $50 \% 15 \mathrm{~min} 74^{\circ} \mathrm{C}$ & $30.0 \mathrm{abc}$ & $0.0 \mathrm{a}$ & $0 \mathrm{a}$ & $0 \mathrm{a}$ \\
\hline $80 \% 10 \mathrm{~min} 130^{\circ} \mathrm{C}$ & $10.0 \mathrm{a}$ & $6.3 \mathrm{ab}$ & $0 \mathrm{a}$ & $0 \mathrm{a}$ \\
\hline $80 \% 15 \mathrm{~min} 150^{\circ} \mathrm{C}$ & $20.0 \mathrm{abc}$ & $0.0 \mathrm{a}$ & $0 \mathrm{a}$ & $0 \mathrm{a}$ \\
\hline L.S.D. at $5 \%$ & 24.4 & 17.2 & 18.2 & 27.3 \\
\hline $\mathrm{CV} \%$ & 33.5 & 45.1 & 17.8 & 69.6 \\
\hline
\end{tabular}

Egypt. J. Agron. 43, No. 2 (2021) 
On the other hand the treatment by microwave power $50 \%$ at $10 \mathrm{~min}$ improved the germination percentage by $12.5 \%$ compared to untreated control in the first experiment. Whilst, both microwave powers $30 \%$ at $10 \mathrm{~min}$ and $30 \%$ at $15 \mathrm{~min}$ improved the germination percentage by 59.7 and $39.9 \%$, respectively, compared to untreated control in the second experiment.

The exposure to microwave power significantly affected germination percentage of C. arvensis seeds at $50 \%$ power for $15 \mathrm{~min}$ and $80 \%$ for both periods of exposure 10 or $15 \mathrm{~min}$. Bebawi et al. (2007) confirmed that the short exposure of seeds to radio frequency and microwave radiation resulted in increasing germination of $C$. arvensis seeds and long exposure caused seed death, which is in agreement with the present results.

For Cuscuta pedicellata weed, the germination percentage was negligible at microwave power $50 \%$ at $10 \mathrm{~min}$. Whereas, microwave power $50 \%$ at $15 \mathrm{~min}$ prevented the germination completely in the first and second experiments. This result in agree with those obtained by Sarić-Krsmanović et al. (2013) who indicated that temperature is one of the most important factors affect seed germination and seedling emergence.

Effect of microwave heating on germination percentage of Ambrosia artemisiifolia (white bursage), A. trifida (Giant ragweed) weeds seeds

In Egypt, Ambrosia artemisiifolia and $A$. trifida considered alien quarantine weeds after risk assessment was made which proved that these weeds can cause great losses to agricultural production and plant sanitary which extends to the human.

Firstly, in the two germination experiments in petri dishes under laboratory for Ambrosia artemisiifolia and $A$. trifida, the obtained results showed that the low germination percentage ranged between $10 \%$ in the first experiment and $20 \%$ in the second experiment. The seedling that survived of $A$. trifida was transplanted to the pot under wire house conditions to complete the cycle stage until flowering (Fig. 1). After 140 days from sowing, the plant height was $1.16 \mathrm{~m}$, root length $15.5 \mathrm{~cm}$ and numbers of fruit branches were 45 branches/plant.

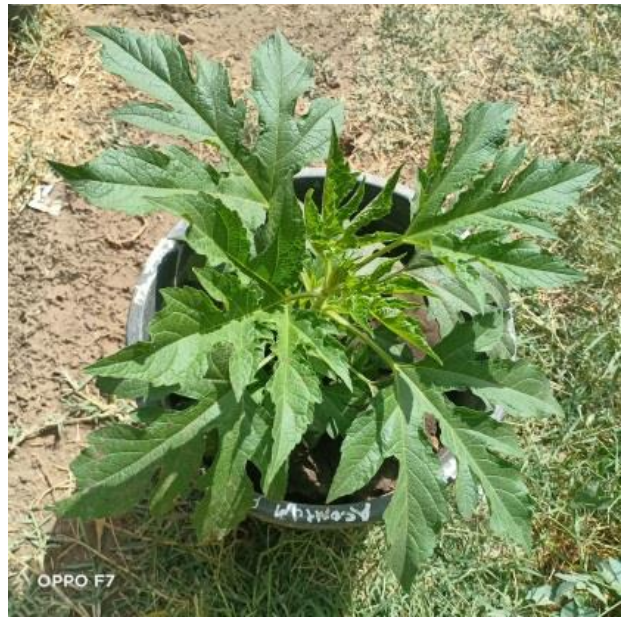

Fig.1. Ambrosia trifida

Secondly, for the other six germination experiments which were conducted by using Gibberellin acid, Potassium nitrate and Thiourea solutions, the obtained results showed that there was no germination percentage completely under all microwave heating treatments and untreated control due to increasing the temperature more than $30^{\circ} \mathrm{C}$ under Egypt conditions during sowing date in May 2020 which, may not be suitable for germination of Ambrosia spp. and may have caused the secondary dormancy of achenes, or the seeds were exposed to pre-export treatments that affected the viability of the seeds, especially the seeds of broad-leaved plants.

Thirdly, direct sowing of Ambrosia spp. achene in the soil, the results reported that the germination percentages were $60 \%$ in the first experiment and $55 \%$ in the second experiment in untreated control, but under all microwave treatments, the germination percentage was $0 \%$.

These results may be due to the complicated seed biology of Ambrosia spp. which has different types of dormancy and need stratification about four weeks at $0^{\circ} \mathrm{C}$ temperature, after that if the conditions are not suitable to germination, seeds can enter secondary dormancy (Baskin \& Baskin, $1980,1998)$. Moreover, the dormancy loss in the natural environment is due to cold-moist conditions (Schutte et al., 2007).

Tetrazolium salt as a Seed Germination Indicator

Because of the very low germination percentage in the previous eight experiments, TTC solution was used to test vitality of Ambrosia spp. seeds. 
In the TTC-test it notices that the percentage of stained seeds was recorded $55 \%$ under untreated control, but under microwave power treatments, the percentages were 20,15 and $0.0 \%$ at 30,50 and $80 \%$ microwave powers, respectively, in the two Ambrosia spp. seeds.

The percentage of unstained seeds was $45 \%$ under untreated control, but under microwave treatments, the percentage increased by increasing the microwave power and the period of exposure, so its mortality percentage increased from 55 to $100 \%$ when the power increased from $30 \%$ for $10 \mathrm{~min}$ to $80 \%$ for $15 \mathrm{~min}$.

Table 3 showed that for microwave ovenheated treatments, the percentages of dead seeds increased compared to untreated control. Moreover, all seeds of Ambrosia spp. were dead (class 0 ) by exposure to microwave power $80 \%$ $10 \mathrm{~min}$.

Exposure of Ambrosia spp. seeds to unsuitable temperature may lead to their entry into secondary dormancy (Baskin \& Baskin, 1980, 1998), so, seeds treated by different microwave powers didn't germinate.

Ambrosia spp. seeds were classified as three classes stained (class 1), dead (class 0), and the seeds had a little cells colored by TTC solution that means this seeds had intermediate viability (class 0.5 ; only parts of the embryo stained) according to Starfinger et al. (2012) (Fig. 2).

Figure 3 presented that the microwave power $80 \%$ and the period $15 \mathrm{~min}$. gave $100 \%$ mortality for all weed spp. except field bind weed.

The emergence percentage of giant ragweed, white bursage, dodder and field bind weed about 40 to $60 \%$, due to some of its species have different types of seed dormancy. Giant ragweed and white bursage were affected greatly by microwave treatments due to exposing their species to unsuitable condition which lead to their entry into secondary dormancy and did not emerge.

Microwave power $50 \%$ was enough to complete mortality of dodder seeds. Grassy weeds as wild oats and darnel have the highest emergence percentage and the microwave treatments at lower power than $30 \%$ power and less exposure time resulted in improvement of the germination percentage, so the mortality degree began with microwave power more than $50 \%$ and exposure time 10 and 15 minute. These results suggested that the viability of grassy weeds is more than that of broad leaved weeds as dodder, field bind weed, Giant ragweed and white bursage.

Oil percentage of soybean seeds and protein contents of wheat grains which were exposed to microwave power

Table 4 showed that the microwave power for devitalize quarantine weed seeds produced significantly increase in oil percent of soybean and in protein of wheat grains, however increasing quantity of sample more than $1.5 \mathrm{~kg}$ resulted in increasing oil percentage in soybean seeds and protein content in wheat grains than those without microwave treatment (control). These results were due to the decrease in moisture and increasing oil or nitrogen percentage/sample, but in case of the samples less than one kilogram, most seeds were burned thus resulted in decreasing the oil or nitrogen percentage. These results are in agree with those obtained by Walde et al. (2002), which found that, drying wheat samples by microwave did not change the total protein content moreover microwave drying helps to reduce power consumption in wheat grinding process.

TABLE 3. Viability classification of the two Ambrosia spp. seeds according to TTC_test

\begin{tabular}{lccc}
\hline \multirow{2}{*}{ Power \% } & \multicolumn{2}{c}{ Percentage of seeds in different classes } \\
\cline { 2 - 4 } Control & Stained= Class 1 & Unstained= Class 0 & Intermediate= Class 0.5 \\
$30 \% 10 \min 24^{\circ} \mathrm{C}$ & 55 & 45 & 0 \\
$30 \% 15 \mathrm{~min} 45^{\circ} \mathrm{C}$ & 20 & 55 & 25 \\
$50 \% 10 \mathrm{~min} 64^{\circ} \mathrm{C}$ & 20 & 65 & 25 \\
$50 \% 15 \mathrm{~min} 74^{\circ} \mathrm{C}$ & 15 & 65 & 20 \\
$80 \% 10 \mathrm{~min} 130^{\circ} \mathrm{C}$ & 15 & 75 & 10 \\
\hline
\end{tabular}

Egypt. J. Agron. 43, No. 2 (2021) 


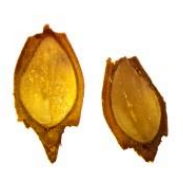

Stained

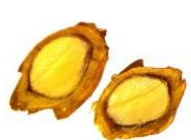

Unstained

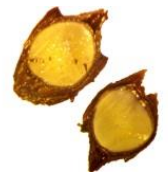

Intermediate

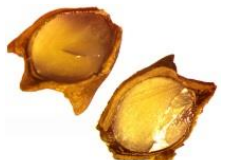

Stained

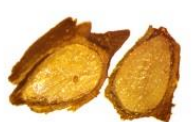

Unstained

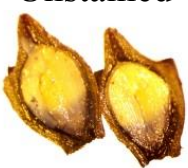

Intermediate $30 \% 10$ minute

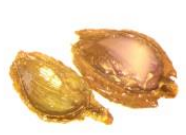

Stained

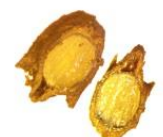

Unstained

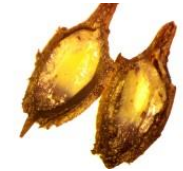

Intermediate $30 \% 15$ minute

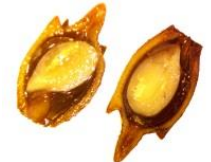

Stained

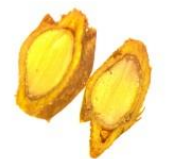

Unstained

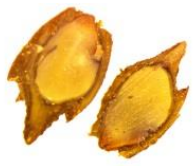

Intermediate

$50 \% 10$ minute

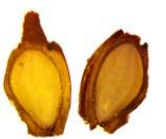

Stained

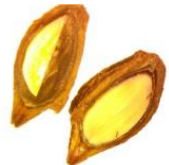

Unstained

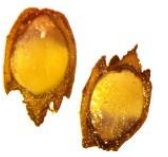

Intermediate

$50 \% 15$

minute

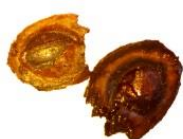

Unstained

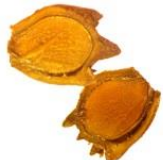

Unstained

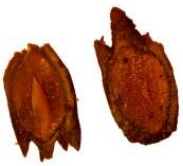

Unstained

$80 \% 10$

minute

Fig. 2. Photos of Ambrosia spp. [Seeds were checked for viability with the TTC-test and classified into different classes]

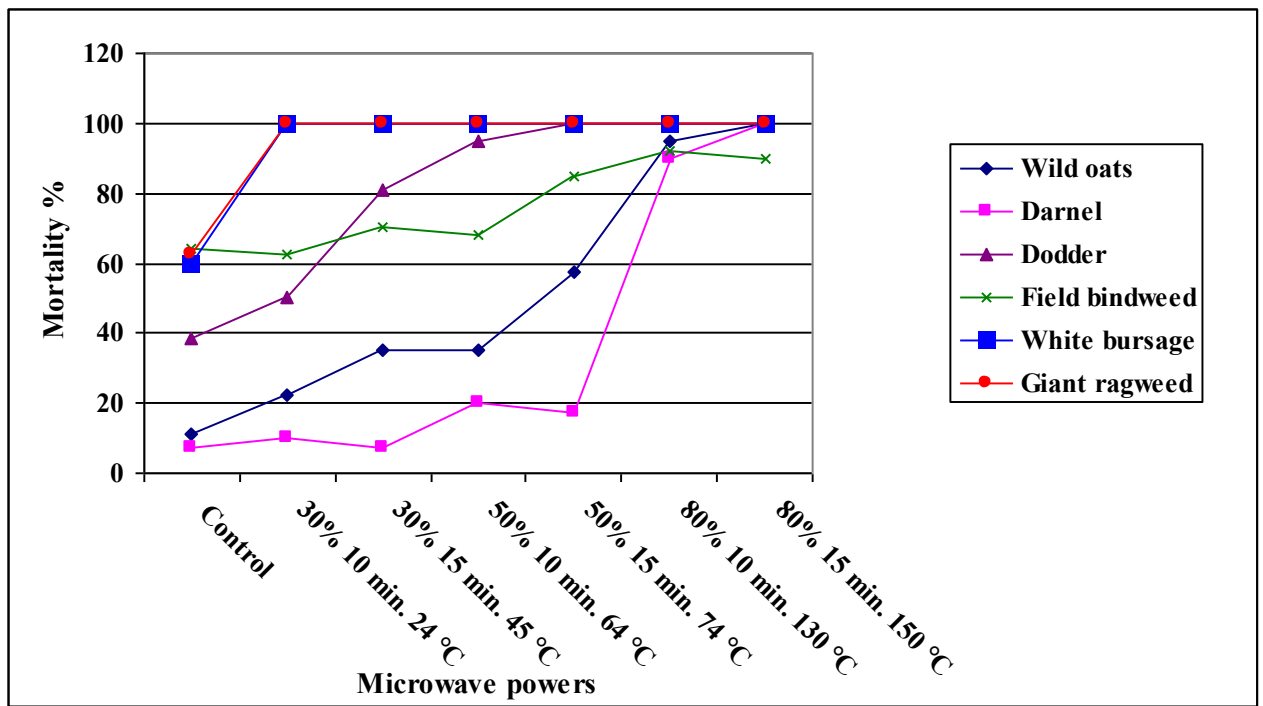

Fig. 3. The relationship between microwave power treatments and mortality percentage of six weed species under studies

TABLE 4. Effect of sample weight on oil percent of soybean seeds and protein content of grain wheat under $50 \%$ for $15 \mathrm{~min}, 7^{\circ} \mathrm{C}$ and $80 \%$ for $15 \mathrm{~min}, 150^{\circ} \mathrm{C}$, respectively

\begin{tabular}{lcc}
\hline Sample weight & Oil Percentage of soybean & Protein Percentage of grain wheat \\
\hline $0.5 \mathrm{~kg}$ & $20.55 \mathrm{a}$ & $15.78 \mathrm{a}$ \\
$1 \mathrm{~kg}$ & $21.45 \mathrm{a}$ & $16.40 \mathrm{ab}$ \\
$1.5 \mathrm{~kg}$ & $23.7 \mathrm{~b}$ & $18.21 \mathrm{~b}$ \\
$2 \mathrm{~kg}$ & $24.45 \mathrm{~b}$ & $19.05 \mathrm{~b}$ \\
Untreated control & $23.7 \mathrm{~b}$ & $15.73 \mathrm{a}$ \\
L.S.D. at $5 \%$ & 1.34 & 2.25 \\
CV\% & 3.2 & 4.8 \\
\hline
\end{tabular}




\section{Conclusion}

Microwave power $80 \%$ for $15 \mathrm{~min}$ prevented the germination of wild oats and darnel completely and reduced germination percentage of field bindweed to $10 \%$. The microwave power $50 \%$, $15 \mathrm{~min}$ was enough to prevent germination of dooder seeds completely. Whereas, Giant ragweed and white bursage did not germinate under all microwave power treatments. Microwave powers $50 \%$ for $10 \mathrm{~min}$ and $80 \%$ for $15 \mathrm{~min}$ had no effect on the oil percentage extracted from soybean seeds and protein content of wheat grains, respectively. It can be concluded that microwave power can completely devitalize quarantine weed seeds, which contaminated in the imported soybean and wheat without affecting oil percentage of soybean or the protein content of wheat grains. More researches in this field are required to investigate the possibility to include more weed seed species and crops.

\section{Reference}

A.O.A.C. (1990) "Official Methods of Analysis", Association of Official Analytical Chemists. $15^{\text {th }}$ ed.. Washington DC.

Baskin, J.M., Baskin, C.C. (1980) Ecophysiology of secondary dormancy in seeds of Ambrosia artemisiifolia. Ecology, 61(3), 475-480.

Baskin, C.C., Baskin, J.M. (1998) "Seeds: Ecology, Biogeography, and Evolution of Dormancy and Germination". San Diego: Academic Press.

Bebawi, F.F., Cooper, A.P., Brodie, G.I., Madigan, B.A., Vitelli, J.S., Worsley, K.J., Davis, K.M., (2007) Effect of microwave radiation on seed mortality of rubber vine (Cryptostegia grandiflora R.Br.), parthenium (Parthenium hysterophorous L.) and bellyache bush (Jatropha gossypiifolia L.). Plant Protection Quarterly, 22(4), 136-142.

Bisceglia, B., De Leo, R., Diaferia, N., (2009) MW pallets disinfestations. Journal of Microwave Power \& Electromagnetic Energy, 43(4), 1-13.

Brodie, G., Hamilton, S., Woodworth, J. (2007) An assessment of microwave soil pasteurization for killing seeds and weeds. Plant Protection Quarterly, 22(4), 143-149.

Brodie, G., Ryan, C., Lancaster, C. (2012) Microwave

Egypt. J. Agron. 43, No. 2 (2021) technologies as part of an integrated weed managementstrategy:Areview.InternationalJournal of Agronomy, 2012(1). DOI:10.1155/2012/636905.

Brodie, G., Khan, J.M., Gupta, D., Foletta, S., Bootes, N. (2017) Microwave weed and soil treatment in agricultural systems. Global Journal of Agricultural Innovation, Research \& Development, 5, 1-14. https://doi.org/10.15377/2409-9813.2018.05.1.

Brodie, G., Khan, M.J., Gupta, D. (2019) Microwave soil treatment and plant growth..Sustainable Crop Production, IntechOpen, DIO: 10.5772/ intechopen.89684.

Brodie, G., Pchelnikov, Y., Torgovnikov, G. (2020) Development of microwave slow-wave comb applicators for soil treatment at frequencies 2.45 and $0.922 \mathrm{GHz}$ (Theory, design, and eExperimental study). Agriculture, 10(12), 604.

Dahlquist, R.M., Prather, T.S., Stapleton, J.J. (2007) Time and temperature requirements for weed seed thermal death. Weed Science, 55(6), 619-625.

Ibrahim, H.E., El-Fadaliy, H.G., El-Shanhorey, N.A. (2016) Effect of microwave on seed germination and plant growth in Acacia sp. (Acacia farnesiana and Acacia saligna). Alexandria Science Exchange Journal, 37(3), 440-450.

Khan, M.J., Brodie, G.I. (2018) Microwave weed and soil treatment in rice production. In: "Rice CropCurrent Developments", Open access peer-reviewed chapter, DOI: 10.5772/intechopen.77952, pp. 99127.

Khan, M.J., Brodie, G., Cheng L., Liu, W., Jhajj, R. (2019) Impact of microwave soil heating on the yield and nutritive value of rice crop. Agriculture, 9(7), 134.

Moon, K.O., Oh, J.B., Kyoung, E.S., Lee, Y.H., Hong, S.H., Kang, B.H. (2013) Heat-treatment effects of agricultural imports for devitalization of quarantine weed seeds. Weed \& Turfgrass Science, 2(2),170175.

Moore, R.P. (1973) Tetrazolium staining for assessing seed quality. In: Seed Ecology: Proceedings of the Nineteenth Easter School in Agricultural Science. W. Heydecker (Ed.), London: Butterworths, pp.347366. 
Peters, J. (2007) "Tetrazolium Testing Handbook". Ithaca: Association of Official Seed Analysts. (AOSA. Contribution to the Handbook on Seed Testing, 29).

Riemens, M.M. (2003) Effects of heating and light exposure on the emergence, germination, viability and dormancy of weed seeds|. Plant Research International B.V., Wageningen July, Note 250, p.36.

Sahin, H. (2014) Effects of microwaves on the germination of weed seeds. Journal of Biosystems Engineering, 39(4), 304-309.

Schutte, B., Regnier, E., Harrison, K., Schmoll, J.T., Forcella, F., Spokas, K. (2007) Predicting late-season emergence for improved giant ragweed management in Ohio. Proceedings of the Weed Science Society of America. 47, 249.

Sarić-Krsmanović, M., Božić, D., Pavlović, D., Radivojević, L., Vrbničanin, S. (2013) Temperature effects on Cuscuta campestris Yunk. seed germination. Pesticidi i Fitomedicina, 28(3), 187193.
Starfinger, U., Sölter, U., Verschwele, A., Karrer, G., Lener, F., Kerepesi, I., Kazinczi, G., Kudsk, P., Mathiassen, K. (2012) A ring test for ragweed seed viability using tetrazolium testing”. In: NEOBIOTA 2012, $7^{\text {th }}$ European Conference on Biological Invasions Pontevedra (Spain). GEIB Grupo Especialista en Invasiones Biológicas (Ed.). 12-14 September 2012, Halting Biological Invasions in Europe.

Tran, V.N. (1979) Effects of microwave energy on the Strophiole, seed coat and germination of Acacia seeds. Australian Journal of Plant Physiology, 6(3), 277-287.

Tran, V.N., Cavanagh, A.K. (1979) Effects of microwave energy on Acacia longifolia. Journal of Microwave Power, 14(1), 21-27.

Walde, S.G., Balaswamy, K., Velu V., Rao, D.G. (2002) Microwave drying and grinding characteristics of wheat (Triticum aestivum). Journal of Food Engineering, 55(3), 271-276.

\section{تأثير التشخين بفرن الميكروويف على إنبات بذور الحشائش في الشحنات المستوردة

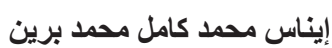 المعمل المركزي لبحوث الحشائش ـ مركز البحوث الزر اعبة ـ الجيزة ـ مصر.}

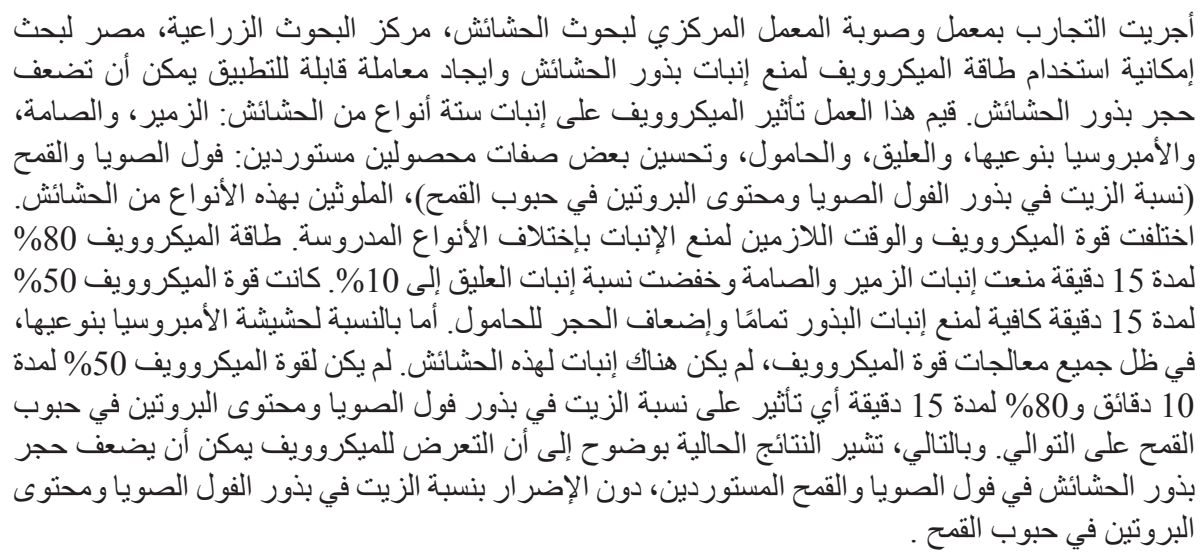

